\title{
New records for the flora of Fujairah Emirate (United Arab Emirates)
}

\author{
V. V. Byalt ${ }^{1 *}$, M. V. Korshunov ${ }^{2}$ \\ ${ }^{1}$ Komarov Botanical Institute of RAS, Prof. Popova Str., 2, St. Petersburg, RU-197376, Russian Federation. \\ E-mails: byalt66@mail.ru,VByalt@binran.ru; ORCID iD: https://orcid.org/0000-0002-2529-4389 \\ ${ }^{2}$ Wadi Wurayah National Park and Reserve, Government of Fujairah, P. O. Box: 1, UAE. \\ ORCID iD: https://orcid.org/0000-0003-1566-171X \\ * Corresponding author
}

Keywords: Acanthaceae, adventive species, Apiaceae, Arabia, Basellaceae, flora of Fujairah, floristic records, Rutaceae.

Summary. During floristic research in 2017-2020 in the Emirate of Fujairah in the United Arab Emirates (UAE), we made new findings that complement the species composition of the flora of vascular plants in the territory of the Emirate and the UAE as a whole. The article provides data on 7 new ergasiophytes and ergasiophygophytes, alien to the Emirate of Fujairah: Asystasia gangetica T. Andersson (Acanthaceae) found growing wild in Dibba, A. gangetica subsp. micrantha (Nees) Y. F. Deng et N. H. Xia (Acanthaceae), as a weed in the nurseries of Dibba, Rul Dadna and Al Bidiya, Centella asiatica (L.) Urb. (Apiaceae), as a weed in Dibba town, Basella alba L. (Basellaceae) cultivated and becomes wild in Dibba town, Citrus $\times$ limon (L.) Osbeck (Rutaceae) cultivated and often found growing wild in Dibba, the village of Sharm and other settlements of the Emirate, Murraya koenigii (L.) Spreng. cultivated and becomes wild in Dibba, Rul Dadna, Al Bidiya and other places, and M. paniculata (L.) Jack (Rutaceae) cultivated and becomes wild in plant nurseries in Dibba and Al Bidiya. Asystasia gangetica, A. micrantha, and Centella asiatica are new alien species for Fujairah Emirate and the UAE, and Basella nigra, Murraya koenigii and M. paniculata are new also for Arabia as a whole. A brief history of the study of the flora of the UAE and a preliminary summary of its species diversity are also given.

\section{Новые находки во флоре эмирата Фуджейра (Объединённые Арабские Эмираты)}

\author{
В. В. Бялт ${ }^{1}$, М. В. Коршунов² \\ ${ }^{1}$ Ботанический институт им. В. Л. Комарова РАН, ул. Профессора Попова, 2, г. Санкт-Петербург, 197376, Россия \\ ${ }^{2}$ Вади Вурайя национальный парк, правительство Фуджейры, Почтовый ящик 1, ОАЭ
}

Ключевые слова: адвентивные виды, Аравия, флора Фуджейры, флористические находки, Acanthaceae, Apiaceae, Basellaceae, Rutaceae.

Аннотация. В ходе флористических исследований в 2017-2020 гг. в эмирате Фуджейра в Объединённых Арабских Эмиратах (ОАЭ) нами были сделаны новые находки, дополняющие видовой состав флоры сосудистых растений территории эмирата и ОАЭ в целом. В статье приводятся данные по 7 новым чужеродным для эмирата Фуджейра видам-эргазиофитам и эргазиофигофитам Asystasia gangetica T. Andersson (Acanthaceae) (найден одичавшим в г. Дибба), A. micrantha (Nees) Y. F. Deng et N. H. Xia (Acanthaceae) (сорное в питомниках г. Диббы, Рул Дадны и Аль Бидии), Centella asiatica (L.) Urb. (Apiaceae) (сорное в г. Дибба), Basella alba L. (Basellaceae) (одичавшее в г. Дибба), Citrus $\times$ limon (L.) Osbeck (Rutaceae) (часто встречается одичавшим в Диббе, Шарме и др. населённых пунктах эмирата), Murraya koenigii (L.) Spreng. (дичает в Диббе, Рул Дадне, 
Аль Бидии и др.), M. paniculata (L.) Jack (Rutaceae) (дичает в питомниках Диббы и Аль Бидии). При этом Asystasia gangetica, A. micrantha и Centella asiatica являются новыми чужеродными видами для Фуджейры и ОАЭ, a Basella nigra, Murraya koenigii, M. paniculata - также для Аравии в целом. Также приведена краткая история изучения флоры ОАЕ и предварительная оценка ее видового разнообразия.

In the course of field research in 2017-2020 during the project "Flora of Fujairah, United Arab Emirates" under a cooperation agreement between the Office of the Crown Prince of Fujairah and the Komarov Botanical Institute of the Russian Academy of Sciences, St. Petersburg (Byalt et al., 2020a, b), and as a result of study of herbarium specimens collected by the authors of this paper, information on the distribution of new adventive (alien) plant species in the territory of the Fujairah Emirate, United Arab Emirates (UAE), was clarified. Due to changes in the species composition of the flora caused by the active development of the infrastructure of the region, the growth of urban agglomerations, and an increase in the recreational load on natural ecosystems, there has been a noticeable increase in the number and distribution of alien plant species in the region.

The study of the processes of anthropogenic transformation of flora and the monitoring of alien species are an important part of regional floristic research (Baranova et al., 2018; Shabana et al., 2020; Zykova et al., 2020). There is still insufficient information about the alien component of the Fujairah flora represented by species that were accidentally introduced by escaping from cultivation (Byalt, Korshunov, 2018).

An active study of the UAE flora began at the end of the 20th century, starting with the floristic works of Jongbloed (1987), Western (1989), Karim (1995), Böer and Eschmann-Grupe (1996), Roshier et al. (1996), Feulner (1997), Böer and Chaudhary (1999), Böer and Al-Ansari (1999), Jongbloed et al. (2000), Jongbloed (Jongbloed et al., 2003) and Karim and Fawzi (2007). Later, Feulner (2011) published an annotated list of plants in the flora of Mount Ruus al-Jebel adding at least 17 species not previously recorded in Eastern Arabia, and a few years later he found a number of rare species in the so-called "Olive Highlands" in the southwest of Fujairah, including a new endemic to the UAE and Oman, Launaea omanensis N. Kilian from family Asteraceae (Feulner, 2014b). G. Brown and S. Sakkir (2004b) published "The vascular plants of Abu Dhabi Emirate". The flora of the Helo mountain wadi (Sharjah Emirate) has been extensively studied by El-Keblawy (2011) and El-Keblawy et al. (2016). An important contribution to the study of the flora of the UAE was made after a series of joint botanical expeditions with the participation of the Kew Herbarium from London (K) and the Sharjah Seed Bank and Herbarium, SSBH. Collaborative research has led to the addition of five new taxa to the UAE flora (Heyller, El-Keblawy, 2013). Recently, Sakkir and Brown (2013) additionally surveyed Jebel Hafit in the Emirate of Abu Dhabi and made several new findings for its flora. The flora of this mountain can be considered the most studied in the UAE (Stuart S., Stuart T., 1998; Sakkir, Brown, 2013).

In the earliest floristic study in the Emirates conducted by Western (1989) approximately 480 species were described. Later, Jongbloed et al. (2003) registered 680 species of higher plants for this territory. According to Brown and Böer (2005), there are 678 vascular plant species in the UAE and the surrounding areas of North Oman, of which about 400 grow in the largest Emirate of Abu Dhabi. In the 2-volume "Flora of UAE", Karim and Fawzi (2007) listed only about 600 species including 70 taxa that were not previously recorded, while some of the previously cited taxa, especially mountain species, were not included in their publication.

Among the local floras, the most studied is the flora of Jebel Hafeet Mountain and the adjacent Al Ain oasis, for which a large number of authors have contributed, including El-Ghonemy (1985), Stuart and Stuart (1998), Jongbloed et al. (2000, 2003), Western (1989), Brown and Sakkir (2004a), Karim and Fawzi (2007). Based on their own data and summarizing the data of all these other authors, Brown and Sakkir (2004a) cited 160 species of vascular plants for this place.

Later, Feulner (2011) published a detailed article on the flora of Mount Ru'us al-Jibal on the Musandam Peninsula, partly in Oman and partly the territory of the Emirate of Ras al-Khaima, UAE, that brought the list of species of higher plants in the UAE to 790. In addition, when surveying the large wadi Helo El-Keblawy (2011) identified about 230 species, including new ones for the country. He suggested that further floristic research could add even more species to the flora of the Emirates. This is well supported by the floristic work of various researchers in recent years (eg. Feulner, 2011, 2014a; Shahid, 2014; Shahid, Rao, 2014a, b, 2015a, b, 2016a, b; Mahmoud et al., 2015, 2016; Gairola et al., 2016; 
Byalt, Korshunov, 2020a-c; Byalt et al., 2020a; Shabana et al., 2020), which revealed the presence of about 40 more plant species new to the UAE. Most of these additions are associated with anthropogenically disturbed sites such as farms, roadsides and lawns, and were most likely introduced, intentionally or accidentally. Only four species identified from mountainous areas are likely to be indigenous. The number of plant species known in the UAE will undoubtedly continue to grow as a result of further field research, as confirmed by the findings we are publishing here. Our research of 2017-2020 has significantly added new data to the list of flora species of Fujairah and the UAE (Byalt et al., 2020a, b; Byalt, Korshunov, 2020a-c, and other unpublished data).

\section{Material and methods}

For the identification of groups of alien species the modernized classification of Schroëder (Schroëder, 1969; Branova et al., 2018) was traditionally used. Latin names of plants are given as in the "Catalogue of Life" (Hassler, 2020) and "Plants of the world online" (POWO, 2020). Materials were transferred to the Herbarium of Komarov Botanical Institute of RAS, BIN RAS (LE, Saint-Petersburg), and duplicates to the Herbarium of Altai State University (ALTB, Barnaul) and the Scientific Herbarium of Fujairah (FSH, Wadi Wuraya, Fujairah).

To determine the status of an alien species, the following criteria were used: a large separation of the finding from the main range, mention of its introduction into a neighboring region, the presence of the species only in culture, as well as its presence exclusively in disturbed habitats (Egorov et al., 2016; Baranova et al., 2018). The new species were discovered in many kinds of disturbed habitats - irrigated circles under cultivated trees, near the fences of irrigated gardens, on wastelands and along roadsides after rains, etc. For each species, data from the herbarium label is given, as well as information on the distribution in the UAE, if available, and, as necessary, brief comments on the distribution in Arabia with the greatest specification for Oman, Qatar, Bahrain and the adjacent territory of Saudi Arabia.

\section{New species in the flora of the Emirate of Fujairah}

As a result of the research, rare and new species for the Emirate were identified, some of which are invasive and potentially invasive in Arabia.
Below are the data for the alien species of vascular plants, new to Fujairah.

Accepted abbreviations: UAE - United Arab Emirates; fl. - with flowers; fr. - with fruits; veg. in a vegetative state; juv. - young, underdeveloped; LE - Herbarium of BIN RAS; FSH [not yet an approved acronym] - Fujairah Scientific Herbarium (Byalt et al., 2020b). The labels are in English as in the original. The numbers in square brackets on labels indicate the place of our research recorded by GPS "[point 776] and others." They are given on the labels for the convenience of working with the herbarium specimens.

Asystasia gangetica (L.) T. Andersson subsp. gangetica (Acanthaceae): "UAE, Fujairah Emirate, Al Dibba town, private nurseries, $0.2 \mathrm{~km}$ South from Al Amerey Nursery, 25⒊'24.07"N, $56^{\circ} 14^{\prime} 6.39^{\prime \prime}$, elevation $48 \mathrm{~m}$ [point 776]: cultivated in nursery, near gates. 7 V 2020, fl., fr. V. V. Byalt, M. V. Korshunov. № 2755" (LE). - Ergasiophygophyte, ephemerophyte. South Asian-Australian species (POWO, 2020). Its natural distribution area is in South Asia and Northern Australia. It is widely cultivated as an ornamental in tropical countries and occasionally runs wild. According to the Global Biodiversity Information Facility (GBIF, 2020), it has been recorded in the USA, Venezuela, China, etc. In Fujairah, as apparently throughout Arabia, Asystasia gangetica subsp. gangetica is sometimes cultivated as an ornamental plant but is rather rare everywhere (Byalt, Korshunov, 2020d). According to GBIF (2020), two points are recorded in southern Oman and on Socotra Island, Yemen, but most likely we are talking about $A$. gangetica subsp. micrantha (see below). In Fujairah and the United Arab Emirates as a whole this species has not been recorded as an alien (adventive) species (Western, 1989; Böer, 2000; Jongbloed et al., 2003; Karim, Fawzi, 2007). It is grown for sale in some private nurseries in $\mathrm{Fu}-$ jairah and very rarely grows wild near plantings (Fig. 1).

Asystasia gangetica subsp. micrantha (Nees) Ensermu (A. micrantha (Nees) Y. F. Deng et N. H. Xia) (Acanthaceae): "UAE, Fujairah Emirate, Al Bidiya, Abu Khalid agricultural nursery. $0.3 \mathrm{~km}$ south from Eid Prayer Ground Bidyah, 2525'15.85"N, $56^{\circ} 20^{\prime} 27.64 " \mathrm{E}$, elevation $18 \mathrm{~m}$. [point 780]: weed in and between plastic pots with cultivated plants. $12 \mathrm{~V}$ 2020, veg. V. V. Byalt, M. V. Korshunov. № 2917" (LE; FSH); "UAE, Fujairah Emirate, Al Bidiya, Al Qalamoon Nursery, $0.3 \mathrm{~km}$ east from Eid Prayer Ground Bidyah, 2525'24.70"N, 56 20'18.77"E, 
elevation $22 \mathrm{~m}$ [point 781]: weed after irrigation in plantation, in and between plastic pots with cultivated plants. 15 V 2020, fl. V. V. Byalt, M. V. Korshunov. № 2931” (LE); "Fujairah Emirate, Rul Dadhna, Plant Nursery $1 \mathrm{~km}$ north-northwest from ADNOC Petrol Station on E99 Rugaylat road, 25 32'11.94"N, $56^{\circ} 21^{\prime} 4.36^{\prime \prime}$, elevation $13 \mathrm{~m}$ [point 788]: weed in plant nursery between pots and on the path between

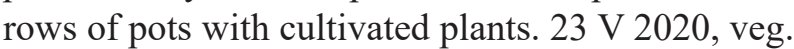
V. V. Byalt, M. V. Korshunov. № 3149” (LE); “UAE, Fujairah Emirate, Al Bidiya, Abu Khalid agricultural nursery. $0.3 \mathrm{~km}$ south from Eid Prayer Ground Bidyah, 252 $5^{\prime} 15.85^{\prime \prime} \mathrm{N}, 56^{\circ} 20^{\prime} 27.64^{\prime \prime} \mathrm{E}$, elevation $18 \mathrm{~m}$. [point 780]: weed in and between plastic pots with cultivated plants and between irrigated lines. 12 V 2020, veg. V. V. Byalt, M. V. Korshunov. № 2880" (LE; FSH); "UAE, Fujairah Emirate, Al Bidiya, Desert Oasis Nursery Bidyah, 0.7 km west from Bidiyah Association for Culture and Folklore, $25^{\circ} 26^{\prime} 9.06^{\prime \prime N}, 56^{\circ} 20^{\prime} 17.72$ "E, elevation $14 \mathrm{~m}$ [point 794]: weed after irrigation in plantation; in plastic pot and between pots; between irrigated lines. 4 VI 2020, fr., veg. V. V. Byalt, M. V. Korshunov. № 3390" (LE; FSH); "UAE, Fujarah Emirate, Al Dibba, Alamarey Nursery, $0.5 \mathrm{~km}$ south from Khalid Hadi

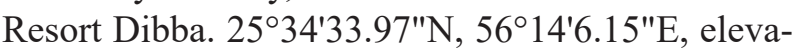
tion $45 \mathrm{~m}$ [point 797]: weed in and between plastic pots with cultivated plants. 13 VI 2020, veg. V. V. Byalt, M. V. Korshunov. № 3565” (LE; FSH); “UAE, Fujairah Emirate, Rul Dadhna, Al Jawhara Plants Nursery, by the unnamed road from E99 to Wadi Zikt dam. $25^{\circ} 30^{\prime} 52.69^{\prime \prime} \mathrm{N}, 56^{\circ} 20^{\prime} 11.79 " \mathrm{E}$, elevation $33 \mathrm{~m}$ [point 805]: weed in and between plastic pots with cultivated plants. 4 VII 2020, veg. V. V. Byalt, M. V. Korshunov. s. n.” (LE; FSH). - Ergaziophyte, colonophyte. Its natural range covers all of Africa, south of the Sahara and part of the Arabian Peninsula. In Arabia, it is found in Yemen (Wood, 1997, as $A$. gangetica s. 1.), the Dhofar province of South Oman (Ghazanfar, 1992; Miller, Morris, 1988, as A. gangetica s. 1.) and southwestern Saudi Arabia (Collenette, 1985, 1999, as A. gangetica s. 1.), but is rather rare everywhere. In Fujairah and the UAE as a whole this subspecies is not registered (Western, 1989; Böer, 2000; Jongbloed et al., 2003; Karim, Fawzi, 2007) and, unlike $A$. gangetica subsp. gangetica, is not cultivated as it has small and less attractive flowers. As revealed by our survey, A. gangetica subsp. micrantha is now a common weed of Fujairah plant nurseries - in Dibba, Rul Dadna and Al Bidiya, where it is found in pots, in damp sand on paths and between rows of pots, usually in shady places with good irrigation, especially in Al Bidiya, where it is found in almost all private nurseries. We

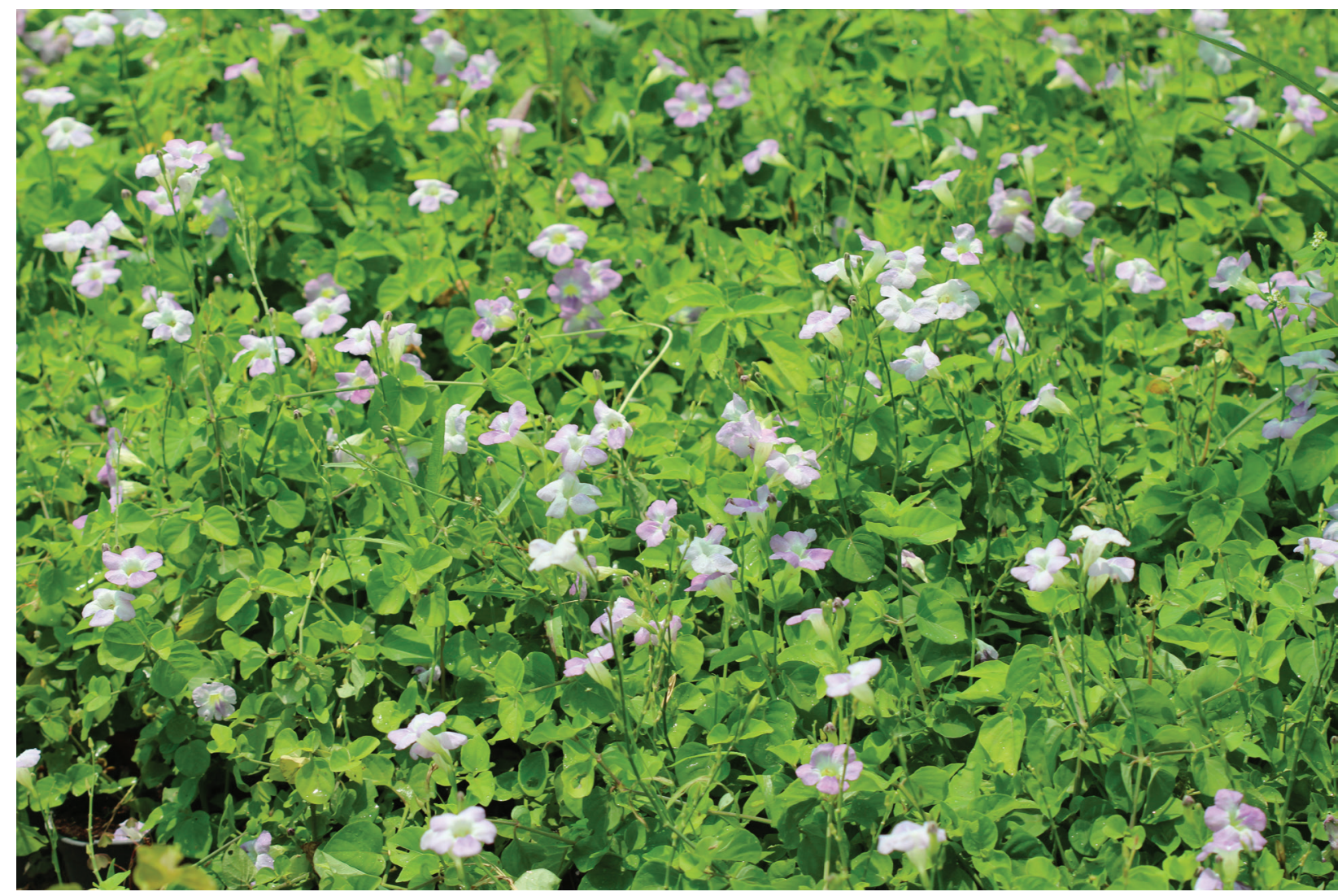

Fig. 1. Asystasia gangetica (L.) T. Anderson is cultivated in a private nursery in Al Bidiya (photo by V. V. Byalt). 
assume that Asystasia gangetica subsp. micrantha was introduced to nurseries with seedlings imported from Pakistan or India, where it is a common weed. It has great invasive potential as it can be distributed with potted plants sold for private gardens and public plantings in settlements.

Centella asiatica (L.) Urb. (Apiaceae): "UAE, Fujairah Emirate, Al Dibba town, Al Shams Nursery, near Dibba Theatre ( $0.1 \mathrm{~km}$ to east), $25^{\circ} 36^{\prime} 9.81^{\prime \prime} \mathrm{N}$, $56^{\circ} 16^{\prime} 41.30^{\prime \prime} \mathrm{E}$, elevation $6 \mathrm{~m}$ [point 767a]: weed in plant market and nursery, in pots with woody plants. 28 IV 2020, veg., fl. V. V. Byalt, M. V. Korshunov. № 2524" (LE; FSH). - Ergaziophyte, ephemerophyte. Its natural distribution area is in sub-Saharan Africa, in the southwest of the Arabian Peninsula, from Iran to East and Southeast Asia, New Zealand, New Guinea and northeastern Australia (POWO,
2020). On the Arabian Peninsula, Centella asiatica occurs in southwestern Saudi Arabia (Collenette, 1985, 1999) and in mountainous Yemen (Wood, 1997), but is very rare everywhere. According to GBIF (2020), two points are fixed on Socotra Island, Yemen and there are absolutely no points for Arabia proper. In Fujairah and the United Arab Emirates as a whole, this species has not been recorded (Western, 1989; Böer, 2000; Jongbloed et al., 2003; Karim, Fawzi, 2007; etc.). We found this plant in a private nursery in Dibba as a weed in pots of woody plants. It forms small sods in several well-watered pots, but it was not possible to find it around the pots, as there was not enough moisture for it (Fig. 2). Apparently, Centella asiatica was accidentally introduced with plant seedlings from India or Pakistan, where this plant is quite common.

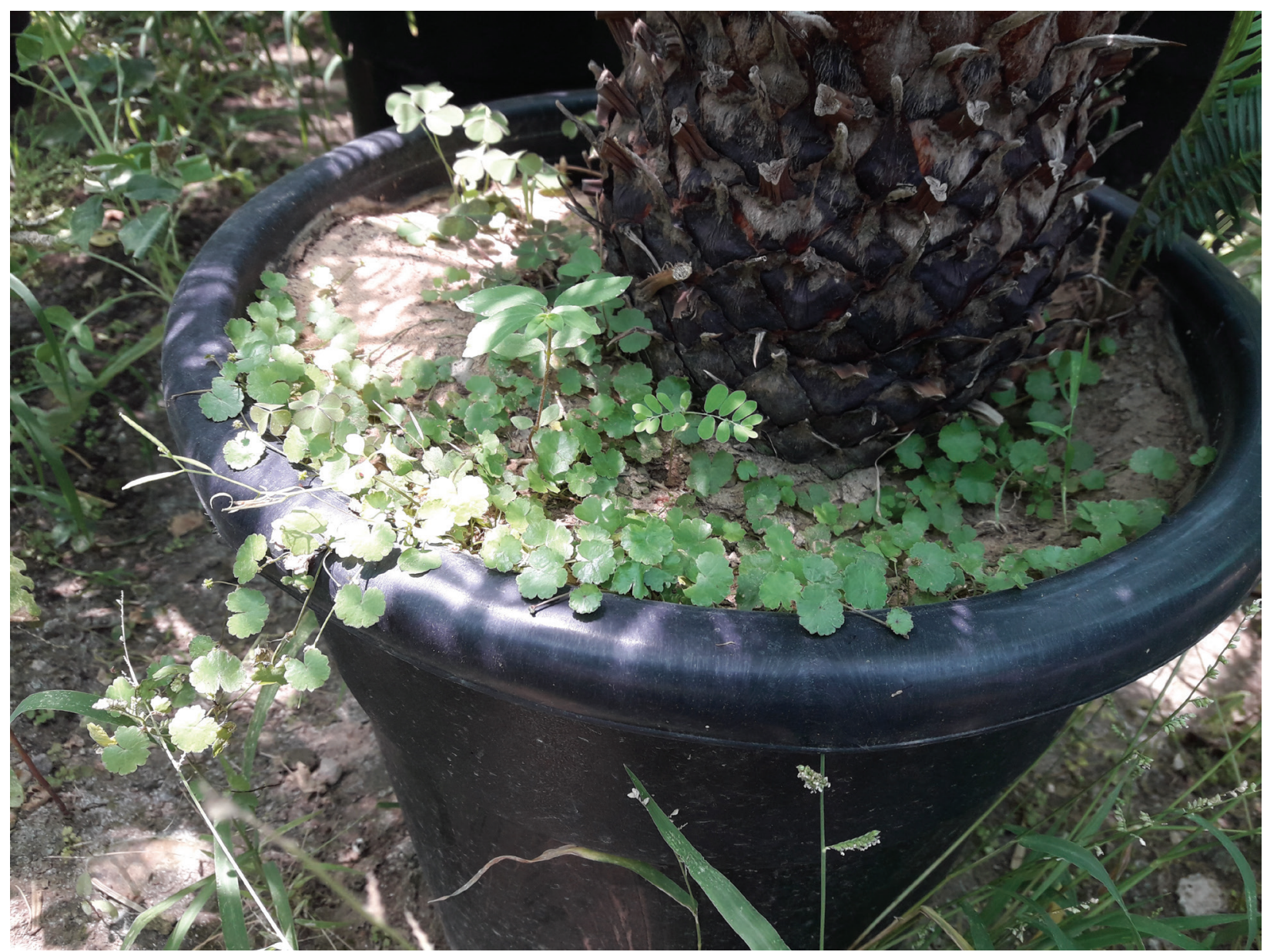

Fig. 2. Centella asiatica (L.) Urb. - weed in pot with cultivated tree in Al Dibba (photo by M. V. Korshunov).

Basella alba L. (Basellaceae): "UAE, Fujairah Emirate, Masafi friday market, E88 Al Dhaid Masafi road, $5.2 \mathrm{~km}$ to Masafi, $25^{\circ} 17^{\prime} 28.28^{\prime \prime} \mathrm{N}$, $56^{\circ} 6^{\prime} 48.62^{\prime \prime} \mathrm{E}$, elevation $370 \mathrm{~m}$ [point 732]: weed on household trash in backside of the market. 3
IV 2020, fr., veg. V. V. Byalt, M. V. Korshunov. № 1666" (FSH); "UAE, Fujairah Emirate, Bidya, $25^{\circ} 25^{\prime} 57.34^{\prime \prime} \mathrm{N}, 56^{\circ} 21^{\prime} 6.57^{\prime \prime} \mathrm{E}$, elevation $10 \mathrm{~m}$ : in backstreet between villas, on drainage near wall of villa. 5 IV 2020, fr., veg. V. V. Byalt, M. V. Kor- 
shunov. № 1763” (FSH); “UAE, Fujairah Emirate, Rul Dhadna, villas and accommodations north from Mina road, on corner with E99 Rugaylat road. $25^{\circ} 31^{\prime} 16.29^{\prime \prime} \mathrm{N}, 56^{\circ} 21^{\prime} 19.69^{\prime \prime}$, elevation $12 \mathrm{~m}$ [pont 755]: in drainage between villas. 17 IV 2020, veg. V. V. Byalt, M. V. Korshunov. № 2210” (FSH); UAE, Fujairah Emirate, town Dibba, $0.9 \mathrm{~km}$ south

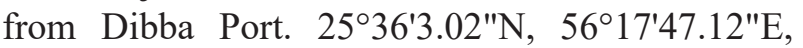
elevation $10 \mathrm{~m}$ [point 760]: on drainage. 19 IV 2020, fr., veg. V. V. Byalt, M. V. Korshunov. № 2237” (FSH); "UAE, Fujairah Emirate, Al Dibba, 0.2 km north from ADNOC Service Station, Al Muhallab (885), $\quad 25^{\circ} 35^{\prime} 45.41^{\prime \prime} \mathrm{N}, \quad 56^{\circ} 16^{\prime} 36.48^{\prime \prime} \mathrm{E}$, elevation $14 \mathrm{~m}$ [point 790]: on drainage near wall of villa. 23 V 2020, fr., veg. V. V. Byalt, M. V. Korshunov. № 3206" (LE; FSH); "UAE, Fujairah Emirate, Al Bidiya, Desert Nurseries Group store 1 (palms), 0.9 $\mathrm{km}$ West from Bidiyah Association for Culture and Folklore, $25^{\circ} 26^{\prime} 9.61^{\prime \prime} \mathrm{N}, 56^{\circ} 20^{\prime} 8.21 " \mathrm{E}$, elevation $14 \mathrm{~m}$ [point 809]: on drainage near wall of labour's accommodation. 16 VII 2020, fr., veg. V. V. Byalt, M. V. Korshunov. № 4123” (FSH). - Ergaziophygophyte, ephemerophyte. It has a natural range in tropical Asia - from India to Indonesia, the Philippines and New Guinea (POWO, 2020). According to our observations, Basella alba is quite often cultivated by immigrants from India and Pakistan, especially in places of compact residence and is used as a salad plant. According to GBIF (2020), there are no points on the Arabian Peninsula. In Fujairah and the United Arab Emirates, this species has not yet been recorded as an alien species (Western, 1989; Böer, 2000; Jongbloed et al., 2003; Karim, Fawzi, 2007). We have repeatedly observed this plant growing wild in places where waters drain near residential buildings (in the settlements of Fujairah there is no centralized sewage system and domestic drainage water flows directly outside from houses and villas) (In these places you can find both Basella seedlings and flowering and fertile plants. We have only ever found this plant growing by the outlet of drainage waters and private gardens with irrigation. We believe that $B$. alba is not yet a potentially invasive species.

Citrus $\times$ limon (L.) Osbeck (Rutaceae): "United Arab Emirates. Emirate of Fujairah, Dibba, $25^{\circ} 36^{\prime} 46.39^{\prime \prime} \mathrm{N}, 56^{\circ} 16^{\prime} 07.85^{\prime \prime} \mathrm{E}, 10 \mathrm{~m}$ alt., gardens in SE part and adjacent streets: in back street, grows wild in irrigated circle under date palm near villa fence. 21 XI 2019, veg. V. V. Byalt, M. V. Korshunov. s. n." (LE); "UAE, Fujairah Emirate, Sharm, $25^{\circ} 28^{\prime} 17.54^{\prime \prime} \mathrm{N}, 56^{\circ} 21^{\prime} 8.03^{\prime \prime E}$, elevation 10-45 m [point 793]: grows wild in irrigation circle with date palm. 28 V 2020, veg. V. V. Byalt, M. V. Korshu- nov. № 3375" (LE; FSH). - Ergasiophygophyte, colonophyte. The fruit tree is most likely a hybrid of a citron and a bitter orange (Gulsen, Roose, 2001), which spontaneously emerged in nature and developed for a long time as a hybridogenic species. Introduced into culture, apparently in Southeast or South Asia, it was first mentioned in the XII century for the territory of India and Pakistan. From here, in the 12th century, the lemon was brought by the Arabs to the Middle East, North Africa, Spain and Italy (Vekhov et al., 1978; Morton, 1987). It is widely cultivated in many countries with subtropical and tropical climates. According to GBIF (2020), the species has been introduced in 37 countries of the world, but there are no distribution points in the Arabian Peninsula, although it is widely cultivated in Oman (Ghazanfar, 1992), Yemen (Wood, 1997), Bahrain (Cornes C., Cornes M., 1989), and other countries. In Fujairah and the United Arab Emirates as a whole, this species is also cultivated with irrigation in private gardens and street plantings near villas but has not yet been registered as an alien species (Western, 1989; Böer, 2000; Jongbloed et al., 2003; Karim, Fawzi, 2007). We have repeatedly observed lemon seedlings and undergrowth in irrigation circles (pits), under date palms (Phoenix dactylifera L., Arecaceae) and other cultivated trees in different settlements of the Emirate. Without watering, lemons do not seem to grow wild, since they require a lot of moisture for normal growth; in landfills, they sometimes germinate in the winter-spring period after rains, but do not survive in the hot summer period.

Murraya koenigii (L.) Spreng. (Rutaceae): "UAE, Fujairah Emirate, Rul Dadhna, ca. $25^{\circ} 31$ 'N, $56^{\circ} 20^{\prime} \mathrm{E}$, elevation $20 \mathrm{~m}$ [point $766 \mathrm{c}$ ]: on roadside, near garden wall. 25 IV 2020, fl. V. V. Byalt, M. V. Korshunov. № 2455” (LE); “UAE. Fujairah Emirate, Al Dibba town, Al Shams Nursery, near Dibba Theatre $\left(0.1 \mathrm{~km}\right.$ to east). $25^{\circ} 36^{\prime} 9.81^{\prime \prime} \mathrm{N}$, $56^{\circ} 16^{\prime} 41.30^{\prime \prime} \mathrm{E}$, elevation $6 \mathrm{~m}$ [point 767]: grows wild on sand in wasteland in place of an abandoned garden or plant nursery, near garden wall without irrigation. 28 IV 2020, veg. V. V. Byalt, M. V. Korshunov. № 2499” (FSH, LE); "Fujairah Emirate, Al Dibba, drainage channel with mango plantation in it, $0.4 \mathrm{~km}$ northwest from Federal Electricity and Water Authority, $25^{\circ} 35^{\prime} 47.57^{\prime \prime N}, 56^{\circ} 15^{\prime} 32.82^{\prime \prime} \mathrm{E}$, elevation $13 \mathrm{~m}$ [768]: growing wild in irrigation circle near wall of villa. 2 V 2020, veg. V. V. Byalt, M. V. Korshunov. № 2588” (LE; FSH); "Fujairah Emirate, Al Dibba, side streets between villas, $0.7 \mathrm{~km}$ south-southwest from Street Number 35, or 
north-northeast from Federal Electricity and Water Authority, $25^{\circ} 36^{\prime} 0.77^{\prime \prime} \mathrm{N}, 56^{\circ} 15^{\prime} 50.95^{\prime \prime} \mathrm{E}$, elevation $12 \mathrm{~m}$ [point 770]: growing wild in irrigation spot near shady wall. 2 V 2020, veg. V. V. Byalt, M. V. Korshunov. № 2610” (LE); “UAE, Fujairah Emirate, Rul Dadhna, Plant Nursery of Abu Abdallah in 1 $\mathrm{km}$ north-northwest from ADNOC Petrol Station on E99 Rugaylat road, 2532'11.94"N, 56 21'4.36"E, elevation $13 \mathrm{~m}$ [point 788]: growing wild in plant nursery near garden wall. $23 \mathrm{~V}$ 2020, veg., fl. V. V. Byalt, M. V. Korshunov. № 3170” (LE; FSH); "Fujairah Emirate, Al Bidya, small villas and gardens $0.9 \mathrm{~km}$ to west-northwest from Green Cost Nursery, Bidiya. $25^{\circ} 25^{\prime} 59.12^{\prime \prime} \mathrm{N}, 56^{\circ} 19^{\prime} 49.63^{\prime \prime} \mathrm{E}$, elevation $38 \mathrm{~m}$ [point 778]: growing wild by garden fence near farm. 11 V 2020, veg. V. V. Byalt, M. V. Korshunov. № 2829” (LE); "UAE, Fujairah Emirate, $\mathrm{Al}$ Aqah, $25^{\circ} 30^{\prime} 6.28^{\prime \prime} \mathrm{N}, 56^{\circ} 21^{\prime} 30.01^{\prime \prime} \mathrm{E}$, elevation $14 \mathrm{~m}$ [point 792]: in irrigation spots near fence

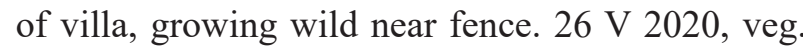
V. V. Byalt, M. V. Korshunov. № 3306” (LE; FSH); "UAE, Fujairah Emirate, Sharm, $25^{\circ} 28^{\prime} 17.54 " \mathrm{~N}$, 56²1'8.03"E, elevation 10-45 m [point 793]: growing wild near wall in irrigation circles in shady side street between villas. 28 V 2020, veg. V. V. Byalt, M. V. Korshunov. s. n." (LE); "UAE, Fujai-

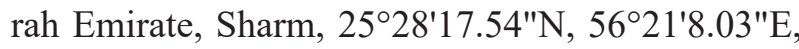
elevation 10-45 m [point 793]: in irrigation circle under date palm. 28 V 2020, veg. V. V. Byalt, M. V. Korshunov. № 3352" (LE; FSH); "UAE, Fujairah Emirate, Al Bidiya, Desert Oasis Nursery Bidyah, $0.7 \mathrm{~km}$ west from Bidiyah Association for Culture and Folklore. $25^{\circ} 26^{\prime} 9.06^{\prime \prime} \mathrm{N}, 56^{\circ} 20^{\prime} 17.72$ "E, elevation $14 \mathrm{~m}$ [point 794]: growing wild between plastic pots in nursery. 4 VI 2020, veg. V. V. Byalt, M. V. Korshunov. № 3426” (LE; FSH). - Ergaziophygophyte, colonophyte. Its natural range extends from the Indian subcontinent to China (South Yunnan, Guangdong, South Hainan), Indochina and North Australia (GBIF, 2020; POWO, 2020). According to GBIF (2020), there are no distribution points on the Arabian Peninsula. In Fujairah, UAE, and in Arabia in general, this species is not registered either as a cultivated or as an alien (adventive) species (Colenette, 1985; Cornes C., Cornes M., 1989; Western, 1989; Migahid, 1996; Wood, 1997; Böer, 2000; Jongbloed, 2003; Karim, Fawzi, 2007; Ghazanfar, 2007; Norton et al., 2009; etc.). From our observations, Murraya koenigii is rather often cultivated by immigrants from India and Pakistan, especially in places compact residence, as it is used as a spice (curry) in cooking. We have repeatedly observed this plant growing wild (sometimes in large quantities) in planting sites in gardens and orchards, plant nurseries and in irrigation circles near residential buildings. In these places, you can find both seedlings, undergrowth and even flowering and fertile plants of clearly self-sown origin, sometimes forming whole clusters of different ages. Very rare $M$. koenigii is found in a feral state near the fences of gardens, there is a flow of water from under the fence. Apparently, a potentially invasive species.

Murraya paniculata (L.) Jack (Rutaceae): "UAE, Fujairah Emirate, Al Bidiya, Abu Khalid agricultural nursery. $0.3 \mathrm{~km}$ south of Eid Prayer Ground Bidyah, 252 25'15.85"N, 56²0'27.64"E, elevation $18 \mathrm{~m}$ [point 780]: cultivated in plastic pots

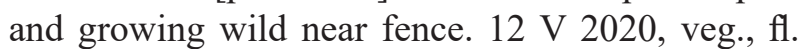
V. V. Byalt, M. V. Korshunov. № 2897” (LE; FSH); "UAE, Fujarah Emirate, Al Dibba town, Alamarey Nursery, $0.5 \mathrm{~km}$ south from Khalid Hadi Resort Dibba. $25^{\circ} 34^{\prime} 33.97^{\prime \prime} \mathrm{N}, 56^{\circ} 14^{\prime} 6.15^{\prime \prime} \mathrm{E}$, elevation 45 $\mathrm{m}$ [point 797]: growing wild near wall of greenhouse. 13 VI 2020, veg. V. V. Byalt, M. V. Korshunov. № 3578” (LE; FSH). - Ergasiophygophyte, ephemerophyte. Its natural distribution ranges from the Indian subcontinent to Southeast Asia, New Guinea and Vanuatu in Oceania (POWO, 2020). According to GBIF (2020), the species has been introduced into 26 countries around the world, but sites on the Arabian Peninsula are missing from this database. In Arabia, in general, this species is not registered as an alien (Colenette, 1989; Cornes C., Cornes M., 1989; Western, 1989; Migahid, 1996; Wood, 1997; Böer, 2000; Jongbloed et al., 2003; Ghazanfar, 2007; Karim, Fawzi, 2007; Norton et al., 2009; etc.), although it is found on the sites of large plant markets and nurseries in Dubai and Abu Dhabi (eg. Plants World, 2020). According to our observations, Murraya paniculata, like M. koenigii, is rather often cultivated in Fujairah (Byalt, Korshunov, 2020d), but not as a curry seasoning (it has no specific spicy taste and smell at all), but as a flowering ornamental shrub with large white and fragrant flowers. We have repeatedly observed this plant in culture, but it rarely grows wild. Only twice have we encountered wild plants of this species in plant nurseries in Dibba, near the wall of the greenhouse, and in Al Bidiya, near the fence of the nursery. Apparently, it has a significantly lower invasive potential than M. koenigii.

\section{Acknowledgments}

The work was performed as part of a state assignment on a planned topic "Vascular plants of Eurasia: taxonomy, flora, plant resources" 
№ AAAA-A19-119031290052-1. The authors express their gratitude to His Excellency Salem Al Zahmi (Director of H. H. Crown-Prince Office) and to Dr. Vladimir M. Korshunov (General Zoologist of Wadi Wurayah National Park and Reserve Department, Government of Fujairah) for their assistance in conducting field work and for their great contribution to the implementation of this study.

\section{Благодарности}

Работа выполнена частично в рамках государственного задания по плановой теме
«Сосудистые растения Евразии: систематика, флора, растительные ресурсы» № AAAA-A19-119031290052-1. Авторы выражают благодарность Его Превосходительству Салему аль Захми (Директору офиса Наследного Принца), а также к. б. н. В. М. Коршунову (главному зоологу Департамента Вади Вурая национального парка, Правительства эмирата Фуджейра), за помощь в проведении полевых работ и за большой вклад в реализацию настоящего исследования.

\section{REFERENCES / ЛИTEPATУPA}

Baranova O. G., Shcherbakov A. V., Senator S. A., Panasenko N. N., Sagalaev V. A., Saksonov S. V. 2018. The main terms and concepts used in the study of alien and synanthropic flora. Phytodiversity of Eastern Europe 12, 4: 4-22. [In Russian] (Баранова О. Г., Щербаков А. В., Сенатор С. А., Панасенко Н. Н., Сагалаев В. А., Саксонов $\boldsymbol{C}$. B. Основные термины и понятия, используемые при изучении чужеродной и синантропной флоры // Фиторазнообразие Восточной Европы, 2018. Т. 12, № 4. С. 4-22). DOI: 10.24411/2072-8816-2018-10031

Böer B. 2000. Annotated check-list for plants in the United Arab Emirates. Abu Dhabi: Emirates Natural History Group, Al Ain and Dubai: Zodiac Publishing. 91 pp.

Böer B., Al-Ansari F. 1999. The vegetation and flora of the United Arab Emirates-a review. In: Proceedings of the Workshop on the Conservation of the Flora of the Arabian Peninsula. Riyadh: NCWCD and IUCN. Pp. 63-77.

Böer B., Chaudhary S. A. 1999. New records for the flora of the United Arab Emirates. Willdenowia 29(1-2): 159-165, maps.

Böer B., Eschmann-Grupe G. 1996. A botanical excursion in the UAE. Tribulus 6, 1: 22-25.

Brown G., Böer B. 2005. Terrestrial Plants. In: The Emirates-A Natural History. Eds. P. Hellyer, S. Aspinall. London: Trident Press. Pp. 141-155.

Brown G., Sakkir S. 2004a. Flora and vegetation of Jebel Hafit. In: Jebel Hafit, a Natural History. Eds. S. Aspinall, P. Hellyer. Abu Dhabi: Emirates Natural History Group, ADCO. Pp. 65-93.

Brown G., Sakkir S. 2004b. The vascular plants of Abu Dhabi Emirate. Internal Research Report, Environmental Research and Wildlife Development Agency (now Environment Agency). Abu Dhabi. 39 pp.

Byalt V. V., Korshunov M. V. 2018. Adventive and invasive plant species in the flora of the United Arab Emirates. In: Actual Issues of Biogeography: Proceedings of the International Conference (St.-Petersburg, Russia, October 9-12, 2018). St. Petersburg: St. Petersburg State University. Pp. 73-76. [In Russian] (Бялт В. В., Коршунов М. В. Адвентивные и инвазивные виды растений во флоре Объединенных Арабских Эмиратов // Актуальные вопросы биогеографии: Материалы Междунар. конф. (г. Санкт-Петербург, Россия, 9-12 октября 2018 г.). СПб.: Санкт-Петербургский гос. ун-т, 2018. С. 73-76).

Byalt V. V., Korshunov M. V. 2020a. A new record of the fern Actiniopteris semiflabellata Pic. Serm. (Pteridaceae) in the United Arab Emirates. Skvortsovia 4, 2: 41-46, col. figs.

Byalt V. V., Korshunov M. V. 2020b. New alien species of flowering plants to the flora of the Arabian Peninsula. Novosti sistematiki vysshikh rasteniy [Novit. Syst. Pl. Vasc.] 51: 118-124. [In English with Russian abstract] (Бялm B. B., Коршунов М. B. Новые чужеродные виды цветковых растений для флоры Аравийского полуострова // Новости сист. высш. раст., 2020. Т. 51. Р. 118-124).

Byalt V. V., Korshunov M. V. 2020c. New woody ergasiophygophytes of the flora of Fujairah Emirate (UAE). Byull. Moskovsk. Obshch. Isp. Prir., Otd. Biol. [Bull. Moscow Soc. Natur. Biol. Ser.] 125, 6: 56-62. [In English] (Бялm B. B., Коршунов М. B. Новые древесные эргазиофигофиты флоры Фуджейры (ОАЭ)) // Бюл. МОИП. Отд. биол., 2020. Т. 125, вып. 6. С. 56-62).

Byalt V. V., Korshunov M. V. 2020d. Preliminary list of cultivated plants in the Fujairah Emirate (UAE). Vestnik of Orenburg State Pedagogical University. Electronic Scientific Journal 4(36): 29-116. [In Russian] (Бялт В. В., Коршунов М. B. Предварительный список культурных растений эмирата Фуджейра (Объединенные Арабские Эмираты) // Вестник Оренбургского государственного педагогического университета. Электронный научный журнал, 2020. № 4(36). С. 29-116). DOI: 10.32516/2303-9922.2020.36.3

Byalt V. V., Korshunov V. M., Korshunov M. V. 2020a. New records of three species of Asteraceae in Fujairah, United Arab Emirates. Skvortsovia 6, 3: 77-86. 
Byalt V. V., Korshunov M. V., Korshunov V. M. 2020b. The Fujairah Scientific Herbarium - a new herbarium in the United Arab Emirates. Skvortsovia 6, 3: 7-29.

Collenette Sh. 1985. An illustrated guide to the flowers of Saudi Arabia. London: Scorpion publishing Ltd. 514 pp., col. ills.

Collenette Sh. 1999. Wildflowers of Saudi Arabia. Riyadh: National Commission for Wildlife Conservation and Development. 799 pp.

Cornes C. D., Cornes M. D. 1989. The Wild Flowering plants of Bahrain. London: IMMEL Publishing. 272 pp., col. ills.

Egorov A. A., Byalt V. V., Pismarkina E. V. 2016. Alien plant species in the north of Western Siberia. In: UArctic Congress 2016. Abstract Book. Oulu: University of the Arctic. P. 105.

El-Ghonemy A. A. 1985. Ecology and Flora of Al Ain Region. Al Ain: UAE University. 205 pp.

El-Keblawy A. 2011. The Wadi Helo protected area: Database for a management plan, environmental and protected areas authority, Sharjah, UAE.

El-Keblawy A. A., Abdel-Hamid A. K., Khafaga T. A. 2016. Mountainous landscape vegetation and species composition at Wadi Helo: Aprotected area in Hajar mountains, UAE. Arid Land Research and Management. DOI: 10.1080/15324982.2015.1136970

Feulner G. 1997. First observations of Olea cf. europaea (the Wild Olive) and Ehretia obtusifolia in the United Arab Emirates. Tribulus 7, 1: 12-14.

Feulner G. R. 2011. The Flora of the Ru'us al-Jibal - the Mountains of the Musandam Peninsula: An Annotated Checklist and Selected Observations. Tribulus 19: 4-153.

Feulner G. 2014a. The flora of Wadi Wurayah National Park - Fujairah, United Arab Emirates. An annotated checklist and selected observations on the flora of an extensive ultrabasic bedrock environment in the northern Hajar Mountains. Report of a baseline survey conducted for EWS-WWF and sponsored by HSBC (December 2012 - November 2014). Dubai, U.A.E. 45 pp. URL: https:/connectwithnature.ae/sites/default/files/fields/field-file/2019-02/ feulner-2014wwnp-plant-survey-reportemnatwwfhsbc.pdf (Accessed 25 November 2014).

Feulner G. R. 2014b. The Olive Highlands: A unique "island" of biodiversity within the Hajar Mountains of the United Arab Emirates. Tribulus 22: 9-34.

Gairola S., Mahmoud T., Shabana H., El-Keblawy A. 2016. Growing knowledge about the floral diversity of United Arab Emirates: new additions and conservation through seed banking. Tribulus 24: 136-143.

GBIF (Global Biodiversity Information Facility). 2020. URL: www.gbif.org (Accessed 30 August 2020).

Ghazanfar S. A. 1992. An annotated catalogue of the vascular plants of Oman and their vernacular names. Scripta Bot. Belg. 2: 1-153.

Ghazanfar S. A. 2007. Flora of the Sultanate of Oman. Vol. 2. Crassulaceae - Apiaceae. Scripta Bot. Belg. 29: $1-220$.

Gulsen O., Roose M. L. 2001. Lemons: Diversity and Relationships with Selected Citrus Genotypes as Measured with Nuclear Genome Markers. Journ. Amer. Soc. Hort. Science 126: 309-317.

Hassler M. 2020. World plants: Synonymic checklists of the vascular plants of the world (version Nov 2018). In: Species 2000 \& ITIS Catalogue of Life, 2020-08-01 Beta. Eds. Y. Roskov, G. Ower, T. Orrell, D. Nicolson, N. Bailly, P. M. Kirk, T. Bourgoin, R. E. DeWalt, W. Decock, E. van Nieukerken, L. Penev. Species 2000: Naturalis, Leiden, the Netherlands. URL: www.catalogueoflife.org/col (Accessed 30 October 2020).

Jongbloed M. 1987. The Living Desert. Arabian Heritage Series. Dubai, U.A.E: Motivate Publishing. 104 pp.

Jongbloed M., Feulner G., Böer B., Western, A. R. 2003. The Comprehensive Guide to the Wild Flowers of the United Arab Emirates. Abu Dhabi, UAE: Environmental Research and Wildlife Development Agency. 576 pp., col. ills.

Jongbloed M., Western R. A., Böer B. 2000. Annotated check-list of plants in the U.A.E. Dubai: Zodiac Publishing. $91 \mathrm{pp}$.

Karim F. M. 1995. Some new and interesting records for the flora of the United Arab Emirates. Candollea 50, 1: 25-31.

Karim F. M., Fawzi N. M. 2007. Flora of the United Arab Emirates. 2 vols. Al Ain: United Arab Emirates University. (UAE University Publications; 98). Vol. 1, 444 pp., ills.; Vol. 2, 502 pp., ills.

Mahmoud T., Gairola S., El-Keblawy A. 2015. Parthenium hysterophorus and Bidens pilosa, two new records to the invasive weed flora of the United Arab Emirates. J. New Biological Reports 4(1): 26-32.

Mahmoud T., Gairola S., Hatem Sh., El-Keblawy A. 2016. Contribution to the flora of United Arab Emirates: Glinus lotoides L. (Molluginaceae) and Senna occidentalis L. (Fabaceae) two new records. Biodiversity Journal 7, 2: 223-228.

Migahid A. M. 1996. Flora of Saudi Arabia, ed. 4. Vol. 1, 2. Riyadh: King Saud University Press. Vol. 1. 252 pp., ills. Vol. 2. 282 pp., ills.

Miller A. G., Morris M. 1988. Plants of Dhofar, the southern region of Oman: traditional. economic and medicinal uses. Muscat: Diwan of Royal Court, Sultanate of Oman. 361 pp., ills. 
Miller A. G., Morris M. 2004. Ethnoflora of Soqotra Archipelago. Edinburgh: The Royal Botanic Garden. 759 pp., col. ills.

Morton J. F. 1987. Lemon. In: Fruits of Warm Climates. Purdue University. Pp. 160-168.

Norton J. A., Abdul Majid S., Allan D.R., Al Safran M., Böer B., Richer R. 2009. An Illustrated Checklist of the Flora of Qatar. Doha: Unesco office. 95 pp., col. ills.

Plants World. 2020. URL: https://plantsworld.ae/products/murraya (Accessed 15 October 2020).

POWO (Plants of the World Online). 2020. URL: http://plantsoftheworldonline.org (Accessed 15 October 2020).

Roshier D. A., Böer B. B., Osborne P. E. 1996. The vegetation of Abu Dhabi and a preliminary classification of its plant associations. In: An introduction to the wildlife and habitats of the United Arab Emirates. Ed. P. E. Osborne. Abu Dhabi. Pp. 50-65.

Sakkir S., Brown G. 2013. New records for the vascular flora of Jebel Hafit, Abu Dhabi Emirate by Sabitha. Tribulus 22: 62-65, figs. 1-8.

Schroëder F.-G. 1969. Zur Klassifizierung der Antropochoren. Vegetatio 16(5-6): 225-238.

Shabana H. A., Gairola S., Mahmoud T. 2020. Tridax procumbens L. (Asterales, Asteraceae), a new record to the flora of the United Arab Emirates. Biodiversity Journal 11(4): 889-896. DOI: 10.31396/Biodiv.Jour.2020.11.4.889.896

Shahid M. 2014. New records for two alien Asteraceae species in the United Arab Emirates. J. New Biological Reports 3(2): 115-119.

Shahid M., Rao N. K. 2014a. New records of two species of Caryophyllaceae in the flora of the United Arab Emirates. Tribulus 22: 66-68.

Shahid M., Rao N. K. 2014b. Datura ferox and Oldenlandia corymbosa: New record to the UAE flora. J. New Biological Reports 3(3): 170-174.

Shahid M., Rao N. K. 2015a. First record of the two Asteraceae species from the United Arab Emirates. J. New Biological Reports 4(3): 215-218.

Shahid M., Rao N. K. 2015b. New records for the two Fabaceae species from the United Arab Emirates. J. New Biological Reports 4(3): 207-210.

Shahid M., Rao N. K. 2015c. New records of eight plant species in the United Arab Emirates. Tribulus 23: 122-128.

Shahid M., Rao N. K. 2016a. New flowering plant species records for the United Arab Emirates. Tribulus 24: 131-136.

Shahid M., Rao N. K. 2016b. Three new Malvaceae species to the flora of the United Arab Emirates. Intern. Journ. Biodivers. Spec. Research 1: 39-44.

Stuart C., Stuart T. 1998. Plants of Jebel Hafit. In: The Natural History, Geology and Archaeology of Jebel Hafit. Ed. R. Hornby. Abu Dhabi: Emirates Natural History Group. Pp. 83-92.

TROPICOS. 2020. https://www.tropicos.org/home (Accessed 30 August 2020).

Vekhov V. N., Gubanov I. A., Lebedeva G. F. 1978. Kulturnyye rasteniya SSSR [The cultural plants of USSR]. Ed. T. A. Rabotnov. Moscow: Mysl. 336 pp. [In Russian] (Вехов В. Н., Губанов И. А., Лебедева Г. Ф. Культурные растения СССР. Отв. ред. Т. А. Работнов. М.: Мысль, 1978. 336 с.).

Western A. R. 1989. The flora of the United Arab Emirates: an introduction. Al Ain: United Arab Emirates University. 188 pp., col. ills., maps.

Wood J. R. I. 1997. A handbook of the Yemen Flora. London, Kew: Royal Botanic Gardens. 434 pp., col. ills.

Zykova E. Yu., Shaulo D. N. 2020. Findings in the flora of Novosibirsk Region. Turczaninowia 23, 3: 58-66. [In Russian] (Зыкова Е. Ю., Шауло Д. Н. Находки во флоре Новосибирской области // Turczaninowia, 2020. Т. 23, № 3. C. 58-66. DOI: 10.14258/turczaninowia.23.3.6 